\title{
The Role of Opioid Receptor Phosphorylation and Trafficking in Adaptations to Persistent Opioid Treatment
}

\author{
Emma E. Johnson MacDonald J. Christie Mark Connor \\ Pain Management Research Institute, Kolling Institute, University of Sydney at Royal North Shore Hospital, \\ St. Leonards, Australia
}

\section{Key Words}

Opioid receptor trafficking · Phosphorylation •

G-Protein-coupled receptor kinase $\cdot$ Morphine, chronic

\begin{abstract}
$\mu$-Opioid receptor activation underpins clinical analgesia and is the central event in the abuse of narcotics. Continued opioid use produces tolerance to the acute effects of the drug and adaptations that lead to physical and psychological dependence. Continued $\mu$-receptor signaling provides the engine for these adaptations, with most evidence suggesting that chronic agonist treatment produces only limited alterations in primary $\mu$-opioid receptor signaling. Here we examine agonist regulation of $\mu$-opioid receptor function, and whether this is altered by chronic treatment. Receptor phosphorylation is thought to be the key initial event in agonist regulation of the $\mu$-opioid receptor, providing a signal for acute receptor desensitization and also subsequent receptor resensitization. Morphine appears to produce qualitatively and quantitatively different $\mu$-receptor phosphorylation than other agonists, but the consequences of this remain obscure, at least in neurons. There is no evidence that agonist-induced $\mu$-opioid receptor phosphorylation changes in chronically morphine-treated animals, al-
\end{abstract}

though receptor regulation appears to be altered. Thus, as receptor phosphorylation and resensitization appear to maintain continued signaling through the $\mu$-opioid receptor, these two events are crucial in facilitating adaptations to chronic opioid treatment, and the possibility that agonist-specific phosphorylation can contribute to the development of different adaptations remains open.

Copyright (c) 2005 S. Karger AG, Basel

\section{Introduction}

Opioid receptor activation is the mainstay of clinical analgesia and the central event in the abuse of heroin and other narcotics. Of the four identified $\mathrm{G}$ protein-coupled opioid receptors, it is the $\mu$-opioid receptor that is the primary target of analgesics and drugs of abuse. The underlying mechanisms of opioid tolerance and dependence are not fully established, although these phenomena are known to involve adaptations at opioid-sensitive synapses and in opioid-sensitive neural circuits [1-5; for review of early studies see 6]. There is also increasing evidence that $\delta$ - and $\kappa$-opioid and ORL-1 receptor systems are important for modulating the acute effects of $\mu$-opioid receptor activation, as well as being critical for some of the adaptations that accompany prolonged $\mu$-opioid agonist

\section{KARGER}

Fax +4161306 1234 E-Mail karger@karger.ch www.karger.com
(C) 2005 S. Karger AG, Basel

1424-862X/05/0146-0290\$22.00/0

Accessible online at: www.karger.com/nsg 
administration [7]. Adaptation to opioid agonist exposure necessarily involves opioid receptor signaling and this review will examine how this receptor signaling changes during chronic opioid treatment, with a particular focus on $\mu$-opioid receptor phosphorylation and how this may affect receptor desensitization, receptor trafficking, and subsequent neuronal adaptations. The role of phosphorylation and trafficking in the regulation of $\mathrm{\kappa}-$ and $\delta$-opioid receptors have been reviewed recently $[8$, 9], and reviews of the adaptations in signaling molecules downstream of opioid receptors can be found elsewhere $[6,10]$.

\section{Opioid Receptor Signal Transduction}

\section{Activation}

Opioid receptors signal via activation of heterotrimeric guanine nucleotide-binding proteins ( $\mathrm{G}$ proteins), mostly of the $\mathrm{G}_{\mathrm{i} / \mathrm{o}}$ subclass [11], although as demonstrated for other $\mathrm{G}$ protein-coupled receptors (GPCRs), non$G$ protein-mediated signal transduction by opioid receptors may also be possible [12]. In the absence of ligands, opioid receptors exhibit basal constitutive activity [13, 14] but agonist occupation induces a dramatic increase in receptor-stimulated $\mathrm{G}$ protein turnover. The activated G protein subunits couple to many well-characterized effectors including adenylyl cyclase, mitogen-activated protein kinases, voltage-gated calcium channels and $\mathrm{G}$ protein-activated potassium channels. When the opioid agonist is removed, receptors no longer efficiently activate $\mathrm{G}$ proteins and the heterotrimeric $\mathrm{G}$ proteins reform, effectively ending any further input from the opioid receptors. While this is likely to produce an abrupt end to signaling directly mediated via $\mathrm{G}$ protein subunits (i.e. millisecond deactivation of $\mathrm{G}$ protein-gated inward rectifier potassium channels [15]), the effects of opioid exposure may persist for some time in second-messenger-regulated protein kinase cascades. In these respects, opioid receptors are similar to many other GPCRs and the mechanisms which regulate the activity of other GPCRs are also likely be involved in the regulation of opioid receptor activity.

\section{Acute Desensitization}

When opioid agonist exposure persists beyond a few seconds, it is often possible to detect a decline in the opioid-stimulated response, termed acute desensitization [for review see 16]. In systems where desensitization can be measured rapidly and precisely, $\mu$-opioid receptor sig- naling is abrogated within $3-5 \mathrm{~min}$, and it recovers over about $30 \mathrm{~min}$ (fig. 1). Desensitization is observed for many GPCRs, and it can involve changes in the receptors or signaling proteins and effector molecules $[17,18]$. The most well-characterized desensitization processes involving the receptors themselves are an acute disruption of the capacity of the receptors to interact with $G$ proteins or a sequestration of the receptors away from the cell surface. Opioid receptors are not thought to signal once removed from the cell surface, and the protein-protein interactions necessary for recruitment of opioid receptors to internalization pathways are likely candidates for blocking further receptor interactions with $G$ proteins, thus providing a potential explanation for acute opioid receptor desensitization [19].

\section{Desensitization Mechanisms Not Involving Receptor \\ Phosphorylation}

The focus of this review is the potential role of receptor phosphorylation and trafficking in regulating opioid receptor signaling, but other mechanisms of modulating opioid receptor signaling have been proposed. The most heavily studied of these involve regulators of $G$ proteinsignaling (RGS) proteins, which modify GPCR signaling in various ways [for review see 20, 21]. Different RGS proteins have been suggested to acutely regulate $\mu$-opioid receptor signaling in vivo by acting as GTPase-activating proteins to accelerate the termination of $\mu$-opioid receptor signaling as well as acting in the longer term (hours) by binding the $\mathrm{G}$ protein $\alpha$ subunits required for $\mu$-opioid receptor signaling [22]. Mice lacking RGS9 are more sensitive to the acute rewarding and analgesic actions of morphine, and apparently develop more intense physical dependence but proportionally less analgesic tolerance to the drug [23]. The role of RGS proteins in opioid receptor desensitization has not been directly examined in single neurons.

\section{Phosphorylation and Receptor Regulation}

Many of the processes that can lead to GPCR desensitization involve a change in the phosphorylation state of the receptors, usually an increase in the number of phosphate groups per receptor. Many GPCRs are basally phosphorylated on serine (Ser), threonine (Thr) or tyrosine (Tyr) residues, and ligand-activated receptors can be further phosphorylated by specific GPCR kinases (GRKs) or second-messenger-dependent protein kinases. Receptor phosphorylation can provide binding sites for adaptor or uncoupling molecules such as arrestins [24], it can block the interaction of proteins with 
Fig. 1. A diagram outlining the basic processes involved in the regulation of $\mu$-opioid receptors in response to acute agonist exposure. More details of these processes can be found in the text. A Morphine-activated receptors desensitize quite rapidly and resensitize relatively slowly and incompletely [63, 71]. Morphine-activated receptors are phosphorylated on $\operatorname{Ser}^{375}$ [28], perhaps by a GRK, and may also be phosphorylated by $\mathrm{Ca}^{2+}$-dependent protein kinase (PKC) [49]. Morphine-induced $\mu$-opioid receptor internalization has been observed in some neurons $[65,66]$ but not others [52, 59]. B Agonists such as DAMGO (and etorphine) generally produce a rapid and more complete desensitization of cellular responses than morphine. This acute desensitization reverses within about $20 \mathrm{~min}$ in neurons [76, 88]. These agonists induce more phosphorylation of the $\mu$-opioid receptor than morphine $[28,35]$ and there is rapid and robust internalization and recycling of the $\mu$-receptor in all systems examined.

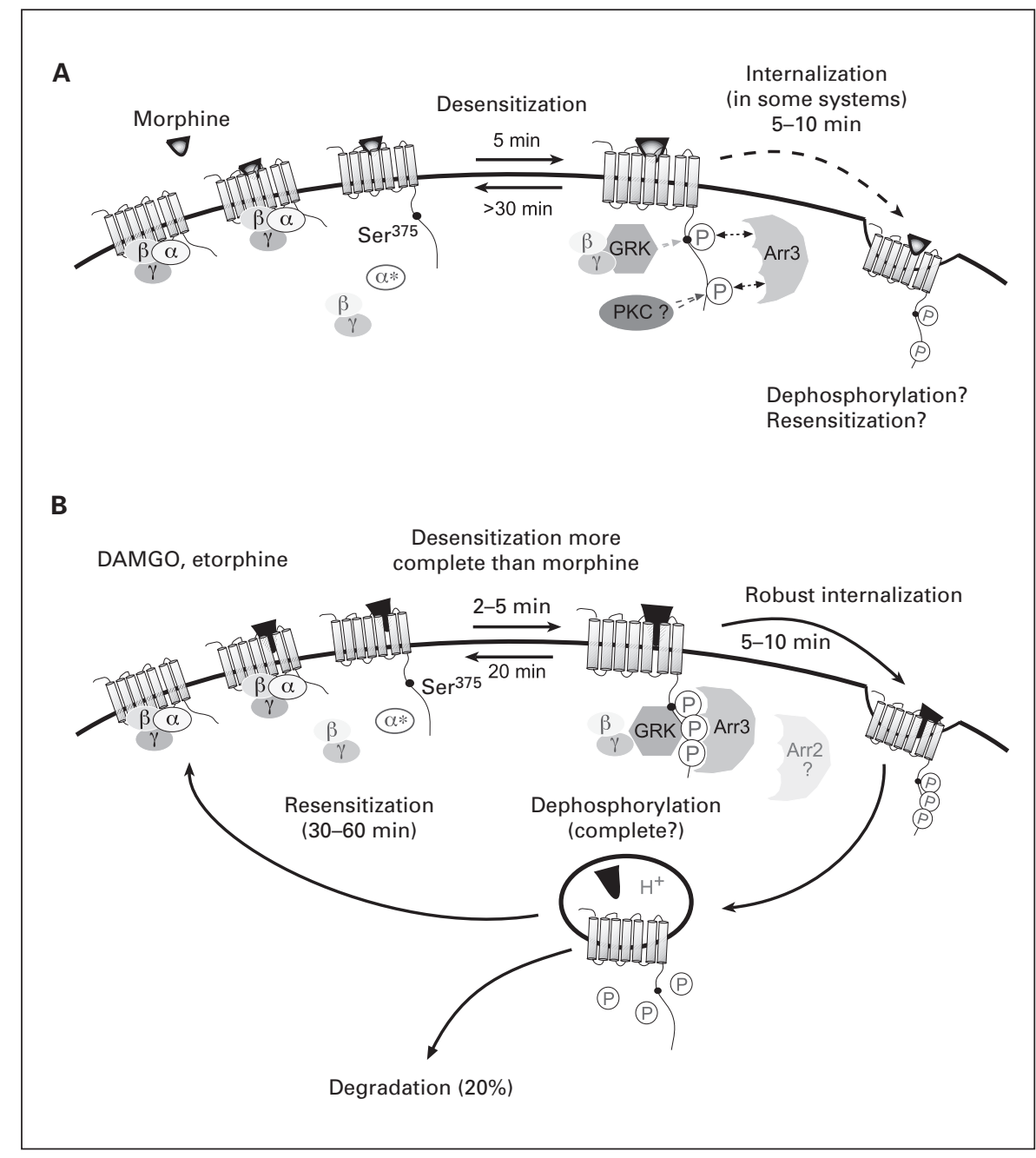

previously accessible regions of the receptor and change the types of $\mathrm{G}$ protein the receptor interacts with [12, $25]$.

A very common pathway of GPCR regulation that is usually initiated by agonist exposure is receptor internalization, which is an example of receptor trafficking. This process has been best defined for the $\beta$-adrenergic receptor. It is initiated by receptor phosphorylation, proceeds via removal of the receptor from the cell surface though clathrin-dependent endocytosis and finishes with the recycling of the dephosphorylated receptor to the cell surface or degradation of the receptor in lysosomes. The signal for receptor internalization is usually provided by multiple phosphorylation of the agonist-occupied receptor by GRKs, these phosphate groups provide a binding site for arrestin, an adaptor protein that acts as a scaffold for the proteins involved in recruiting the receptor to the clathrin pathway [24].

Although there are pathways for GPCR trafficking currently being defined that do not appear to involve GRKs, arrestin or clathrin-mediated endocytosis [24], the present consensus is that opioid receptors are desensitized and internalized in a manner analogous to $\beta$-adrenergic receptors. In the next section we will review the evidence for this, focusing particularly on the evidence for the role of opioid receptor phosphorylation in these processes.

\section{Opioid Receptors Are Phosphoproteins}

There are approximately 20 phosphorylation sites on various Ser, Thr and Tyr residues on the $\mu$-opioid receptor in regions conceivably accessible to protein kinases [26]. These sites are located on all three cytoplasmic loops 
of the receptor and on the intracellular carboxyl tail. Very few studies have established unequivocally which of these potential sites are phosphorylated. Phosphopeptide mapping showed that agonist-induced phosphorylation of rat $\mu$-opioid receptors expressed in HEK293 cells occurred exclusively within a region encompassing the final two transmembrane domains and intracellular tail of the receptor [27]. A phosphopeptide-specific antibody has been used to demonstrate agonist-induced increases in phosphorylation of the intracellular tail residue $\mathrm{Ser}^{375}$ in the $\mu$-opioid receptor [28]. All other studies of opioid receptor phosphorylation have relied on measurements of total receptor phosphorylation and the use of mutant receptors lacking various potential phosphate acceptor sites. This can be problematic because it is difficult to establish whether a change in overall receptor phosphorylation occurs because the mutated phosphorylation sites were truly phosphoacceptor residues, or whether they formed parts of binding sites for protein kinases or other regulatory molecules. There are many unresolved discrepancies regarding the role of phosphorylation of different residues in opioid receptors that have arisen from deletion and mutagenesis studies. The discrepancies between studies probably reflect the different repertoires of protein kinases and other regulatory molecules found in different expression systems, as it has been shown that the cellular environment can determine the phosphorylation pattern of $\beta 2$-adrenergic receptor [29, 30]. Small differences between the sequences of rodent and human receptors may also contribute.

\section{Basal Phosphorylation}

$\mu$-Opioid receptors in native tissue [31] and heterologous systems are constitutively phosphorylated [27, 28, $32-40]$, as measured by incorporation of ${ }^{32} \mathrm{P}$ into unstimulated cells. Information about the kinases responsible for agonist-independent phosphorylation or the role of constitutive phosphorylation in modulating $\mu$-opioid receptor function is limited, although it has been reported that basal (and agonist-stimulated) $\mu$-opioid receptor phosphorylation could be prevented by the protein kinase inhibitor H7, but not a panel of related inhibitors [34]. Basal $\mu$-opioid receptor phosphorylation is increased by activators of $\mathrm{Ca}^{2+}$-dependent protein kinase $[33,39]$ or by co-incubation with the catalytic subunit of protein kinase A [41]. It has been suggested that phosphorylation of some Ser/Thr residues in the carboxyl terminal domain of the $\mu$-opioid receptor may act as a signal to impair receptor trafficking [27], and that phosphorylation of Tyr residues in the 1st and 2 nd intracellular loops of the $\mu$-opioid receptor may regulate signaling efficacy [42], these intriguing possibilities deserve more attention.

\section{Agonist-Induced Phosphorylation}

$\mu$-Opioid receptor phosphorylation following agonist exposure is rapid, with a substantial increase in basal levels detectable only a few minutes after agonist exposure and maximal incorporation of ${ }^{32} \mathrm{P}$ usually occurring after $10-15 \mathrm{~min}$ in native and recombinant receptors [28, 31, 33, 36, 37, 39]. Site-directed mutagenesis experiments have suggested many amino acid residues in the $\mu$-opioid receptor which may be phosphorylated following agonist exposure, including Ser and Thr residues in the carboxylterminal tail as well as Tyr residues scattered throughout the protein. However, only $\mathrm{Ser}^{375}$ of the rat $\mu$-opioid receptor has been definitively demonstrated to be phosphorylated in response to agonist treatment, this was done using a specific antibody generated to phosphoserine $^{375}$ [28]. Ser ${ }^{375}$ was reported to be minimally phosphorylated in unstimulated HEK293 cells, but exposure to a variety of $\mu$-opioid receptor agonists produced a rapid increase in phosphorylation of the residue. The agonist-induced increase in phosphoserine ${ }^{375}$-like immunoreactivity was also observed when $\mu$-opioid receptors were transfected into embryonic cortical neurons [28].

Morphine exposure generally results in less phosphorylation of $\mu$-opioid receptors than other, more efficacious agonists, and recent experiments indicate that this may be because different agonists can promote phosphorylation of different residues. In the study by Schulz et al. [28], morphine produced a significant increase in $\mathrm{Ser}^{375}$ phosphorylation, although the increase was only about $35 \%$ of that produced by the Tyr-D-Ala-Gly-N-Me-PheGly-ol enkephalin (DAMGO), sufentanil or etorphine. This is consistent with data from most previous studies $[28,31-33,35]$, although some studies have reported that morphine did not produce any increase in phosphorylation of the $\mu$-opioid receptor $[36,37]$. Notably, mutation of $\operatorname{Ser}^{375}$ to Ala essentially abolished morphine-induced $\mu$-opioid receptor phosphorylation but only reduced DAMGO-induced phosphorylation by about 50\% [28]. This strongly suggests that DAMGO exposure causes a qualitatively and not just quantitatively different phosphorylation pattern to morphine, although the additional residue(s) phosphorylated in response to DAMGO have not been identified. Conversely, when purified $\mu$-opioid receptors are co-incubated with the catalytic subunit of PKA, morphine but not DAMGO promotes substantial phosphorylation of the receptor at unidentified residues [41]. 
The kinases responsible for agonist-induced phosphorylation of $\mu$-opioid receptors have not been definitively established. Overexpression of GRK2 or GRK3 has been repeatedly shown to produce an increase in $\mu$ opioid receptor phosphorylation in response to agonist exposure [28, 36, 39], including phosphorylation of $\mathrm{Ser}^{375}$. In an elegant experiment, an GRK2 enzyme was genetically engineered to be susceptible to a small molecule inhibitor and co-expressed with $\mu$-receptors in HEK293 cells. In cells overexpressing the GRK2 construct, morphine promoted $\mu$-receptor internalization, and this was completely prevented by the inhibitor of the engineered GRK2 [43]. Other evidence indicates a relatively weak interaction between $\mu$-opioid receptors and GRKs. In particular, agonist stimulation of $\mu$-opioid receptors did not recruit fluorescently tagged GRK2 or 3 to the plasma membrane of HEK293 cells [44]. While available data suggest that GRKs can phosphorylate $\mu$ opioid receptors, strong evidence that they do so in native neurons is lacking.

\section{Opioid Receptor Dephosphorylation}

The protein(s) involved in dephosphorylation of $\mu$ opioid receptors are unknown. An early study reported that morphine-induced phosphorylation of human $\mu$-opioid receptor in Chinese hamster ovary cells was reversed in about $30 \mathrm{~min}$ [35]. By contrast, Schultz et al. [28] reported differential dephosphorylation of $\mathrm{Ser}^{375}$ in rat $\mu$ opioid receptor expressed in HEK293 cells after phosphorylation induced by morphine or DAMGO exposure. The phosphorylation resulting from DAMGO exposure reversed within about 60 min of DAMGO removal, while that produced by morphine did not apparently reverse after $6 \mathrm{~h}$ of being morphine-free. Dephosphorylation of several Tyr residues has been suggested to regulate $\mu$-opioid receptor agonist efficacy in Xenopus oocytes, but this was not directly demonstrated [42], and has not been shown in neurons.

\section{Functional Consequences of Changes in Receptor Phosphorylation}

It is generally assumed that increased receptor phosphorylation is involved in the acute desensitization and trafficking of opioid receptors and the role of receptor phosphorylation in regulating receptor activity during chronic agonist treatment has also received significant experimental attention. However, in direct contrast to these ideas, it has been proposed that agonist-induced $\mu$ opioid receptor phosphorylation promotes an increase in the constitutive activity of the receptor, such that it sig- nals effectively in the absence of agonists [for review see 45]. The site of this phosphorylation has not been established, although it is suggested to be in the 3rd intracellular loop of the receptor, close to a putative calmodulinbinding motif. The kinase(s) responsible for this putative phosphorylation have not been identified, and increases in basal $\mu$-opioid receptor activity have not been demonstrated in intact neurons, but a role for increased constitutive receptor activity in chronically morphine-treated animals has been proposed (see below).

\section{Acute Desensitization}

The role of phosphorylation in acute opioid receptor desensitization has been difficult to define for several reasons. These include the lack of selective reagents for the protein kinases likely to be involved in receptor phosphorylation and the limitations of many of the biochemical assays used to detect a loss of receptor activity [for review see 16]. However, it is clear that acute $\mu$-opioid receptor desensitization can proceed with a time course similar to that of agonist-induced receptor phosphorylation, i.e. $<5 \min [28,31,33,39]$.

Opioid receptor phosphorylation may promote desensitization in several ways. Firstly, receptor phosphorylation could directly interfere with the interaction of receptors with $\mathrm{G}$ proteins, and many of the putative phosphorylation sites in opioid receptors are in the regions of the receptor likely to be involved in $\mathrm{G}$ protein binding. Receptor phosphorylation can inhibit receptor-G protein interactions $[12,46]$ although there is no direct evidence for this for opioid receptors. Alternatively, phosphorylation of receptors can provide a binding site for other proteins that prevent receptor-G protein interaction. One such protein is arrestin, a multifunctional adaptor protein that binds with high affinity to phosphorylated, agonistoccupied GPCR [47, 48]. Two variants of arrestin, arrestin2 and arrestin3, are expressed ubiquitously in the brain. Arrestin binding alone is likely to block interactions of opioid receptors with $G$ proteins [49], but arrestin binding is also crucial for recruiting GPCR to clathrindependent endocytotic pathways, and once removed from the cell surface there is no evidence that $\mu$-opioid receptors continue to signal.

High-affinity arrestin binding to GPCR is associated with an agonist-occupied receptor that has been multiply phosphorylated [48]. Some studies have indicated that agonist-induced phosphorylation of the $\mu$-opioid receptor may involve multiple residues, consistent with formation of high-affinity arrestin-binding sites. The protein kinases most commonly associated with opioid receptor 
phosphorylation leading to arrestin binding are the GRKs. While there are no specific inhibitors of native GRKs, GRK3 knockout mice have been used to explore the role of this protein in $\mu$-opioid receptor regulation. The desensitization of fentanyl- and morphine-induced population spike facilitation in the hippocampus was significantly attenuated in GRK3 null mice, providing strong indirect evidence for the involvement of this kinase in short-term regulation of $\mu$-opioid receptor signaling [50]. Activation of protein kinase $\mathrm{C}$ also facilitates rapid $\mu$ opioid receptor desensitization in neurons [49], perhaps by providing some of the phosphate groups required for arrestin binding.

The evidence that agonist activation of the $\mu$-opioid receptor promotes arrestin binding to the receptor is indirect. The most striking evidence comes from studies in cells heterologously expressing $\mu$-opioid receptors and fluorescent arrestin constructs which showed that cytosolic arrestin 3 moves to the vicinity of the cell surface when receptors are stimulated with a variety of agonists $[36,37,51,52]$. Early experiments suggested that $\mu$-opioid receptor activation only recruited arrestin 3 , although a recent study indicated that under some circumstances arrestin 2 might also be recruited [53]. Arrestin translocation is facilitated by subunits released from $G$ protein heterotrimers, and so, strictly speaking, arrestin translocation may simply reflect receptor activation and not receptor phosphorylation. Mice with a genetic deletion of arrestin 3 have enhanced signaling compared with wildtype animals, reflected in greater agonist-stimulated GTP $\gamma \mathrm{S}$ binding [54-56]. The contribution of receptor desensitization during the GTP $\gamma \mathrm{S}$ assay itself to the final measurement of receptor activity is unknown, so it is not clear whether the apparently enhanced coupling reflects a lack of intra-assay desensitization or an enhanced basal $\mu$-opioid receptor coupling. $\mu$-Opioid receptor desensitization or trafficking has not been examined at the cellular level in either arrestin 3 or GRK3 null mice.

\section{Receptor Trafficking}

The movement of $\mu$-opioid receptors into clathrin-dependent endocytic pathways following agonist binding has been observed in many different expression systems, and is prima facie evidence for agonist-dependent receptor phosphorylation and subsequent arrestin binding, even though the details of the kinases and phosphorylation sites involved are still far from defined. Examining trafficking of opioid receptors in neurons has proved more difficult. An increase in intracellular $\mu$-opioid receptor-like immunoreactivity has been repeatedly shown after exogenous agonist exposure or a physiological stimulus [57-59] both in vivo and in cultured neurons, and the internalization of fluorescent opioid agonists in cultured neurons has also been reported [60]. Interestingly, in contrast to studies of $\mu$-opioid receptors heterologously expressed in HEK293 or AtT-20 cells [32, 61-64], morphine is as efficient as DAMGO at promoting internalization of epitope-tagged $\mu$-receptors in cultured striatal neurons [65]. $\mu$-Opioid receptors heterologously expressed in hippocampal neurons do not internalize in response to morphine [52] and morphine only produces internalization of $\mu$-receptors in the dendrites of cultured nucleus accumbens neurons [66]. Thus local concentrations of protein kinases and arrestins may determine the fate of morphine-activated $\mu$-receptors in neurons, although it has not been possible to identify specific differences in GRK and/or arrestin expression or subcellular localization between neurons that will internalize $\mu$-opioid receptors in response to morphine and those which will not. The absence of significant morphine-induced internalization of the $\mu$-receptor in non-neuronal cells has been attributed to these cells expressing reduced levels of appropriate kinases or arrestins [65], or perhaps that other as yet unidentified molecules are required for most efficient receptor trafficking. While it is assumed that trafficking of native $\mu$-opioid receptors involves the same processes of rapid receptor phosphorylation and arrestin binding as have been shown in heterologous expression systems, direct evidence for this is sparse. Importantly, significant internalization of $\mu$-opioid receptors occurred during application of analgesic doses of DAMGO to the dorsal horn of the spinal cord, indicating that receptor trafficking did not terminate effective receptor signaling [58].

\section{Resensitization}

The presumed link between $\mu$-opioid receptor internalization and desensitization has led to the idea that $\mu$ opioid receptor recycling to the cell surface is a major mechanism for the resensitization of receptor signaling $[19,67-69]$. The existence of a specific pathway for $\mu$ opioid receptor recycling has been identified [68], and it is presumed that the $\mu$-opioid receptor is dephosphorylated somewhere during this process. However, as outlined above, phosphatases responsible for $\mu$-opioid receptor dephosphorylation have not been identified, and there is no direct evidence that recycled $\mu$-opioid receptors have fewer phosphorylated residues, or that any phosphates presumably removed during the trafficking process are those added in response to agonist. Intriguing 
Fig. 2. A diagram outlining how the basic processes involved in the regulation of $\mu$ opioid receptors may be altered in chronically agonist-treated animals. A $\mu$-Opioid receptors desensitize more rapidly and completely in chronically morphine-treated animals and their recovery from desensitization is greatly slowed [75]. $\mu$-Opioid receptor trafficking persists in chronically morphine-treated animals [86], but whether morphine induces receptor internalization in these animals is an open question. B Chronic treatment with agonists such as DAMGO (and etorphine) produces a significant downregulation of $\mu$-opioid receptors [82, 94-96], which may be associated with increased receptor degradation. Nothing is known about acute cellular responses to opioid agonists in neurons from animals chronically treated with agonists other than morphine. Treatment with both morphine and etorphine has been reported to alter the expression of proteins involved in receptor trafficking [89, 90, 94].

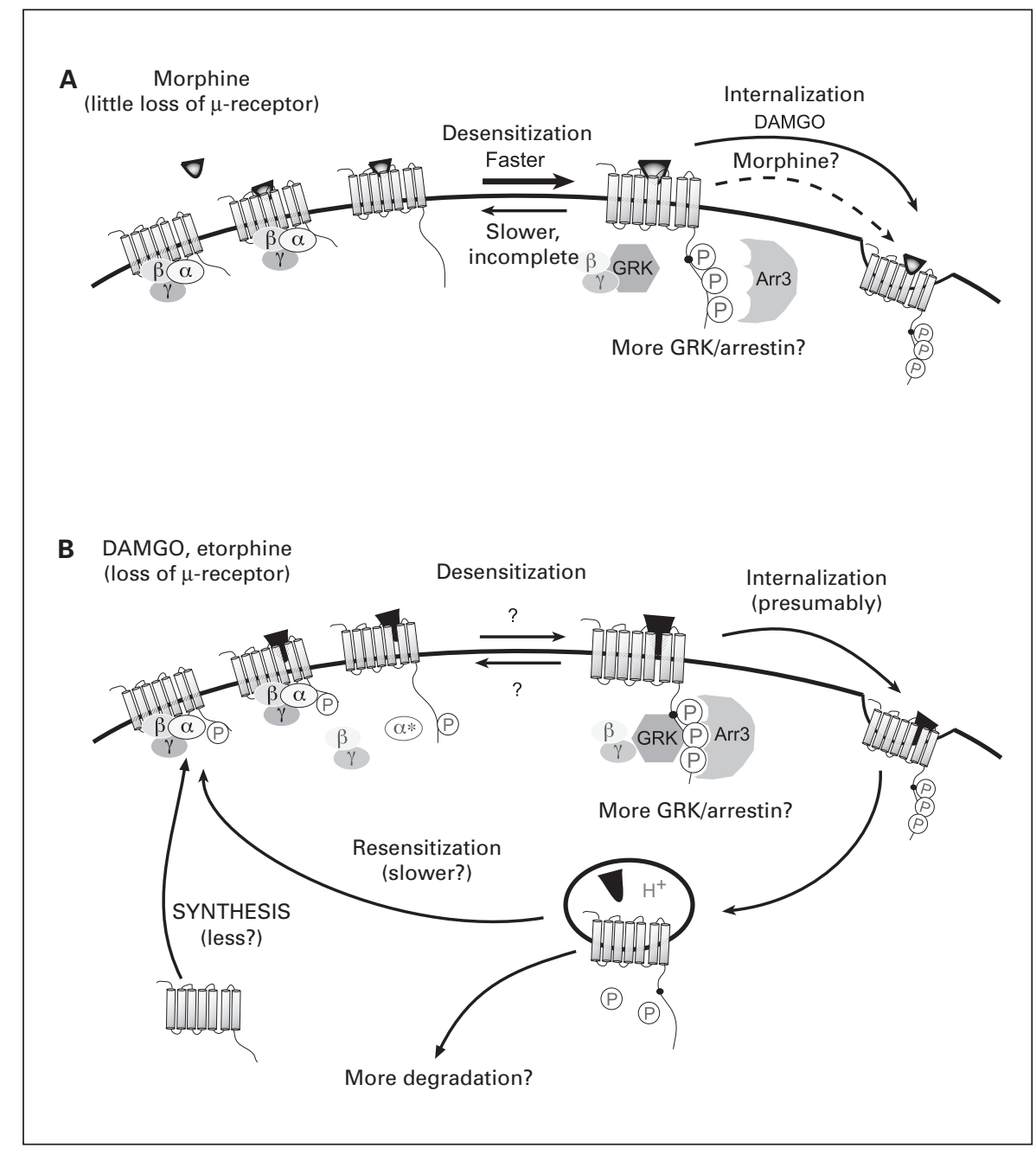

evidence has been provided suggesting that $\mu$-opioid receptors that have undergone one round of receptor trafficking and been reinserted in the plasma membrane are not in the same state as they were before agonist application. Using a genetically engineered GRK2 construct, it was shown that blocking the activity of over-expressed GRK2 prevented initial morphine-induced internalization of $\mu$-opioid receptors [43]. However, continued blockade of this enzyme did not prevent the re-internalization of receptors that occurred in the continued presence of morphine, suggesting that GRK2 was not involved in this process [43]. Whether recycled receptors have fewer or different phosphorylated residues from receptors that have not been exposed to morphine remains to be established.

\section{Phosphorylation, Desensitization and Trafficking in Opioid Tolerance and Adaptation}

Because receptor tolerance and opioid-induced neuronal adaptations occur after acute receptor desensitization, it is tempting to speculate that mechanisms of acute receptor regulation might be linked to the induction or maintenance of long-term tolerance and adaptation. In particular, a key role for the process of receptor trafficking in the induction of tolerance and neuronal adaptations has been proposed by many investigators, and despite broad agreement about the biochemical mechanisms of desensitization, trafficking and receptor resensitization, the significance of these events has been hotly debated (fig. 2). 


\section{The Role of Trafficking in Regulating $\mu$-Opioid Receptor Signaling}

There are two competing ideas regarding the role of $\mu$-opioid receptor trafficking in the induction or maintenance of long-term tolerance and adaptation. One hypothesis is that the internalization of $\mu$-opioid receptors terminates signaling and retards the development of adaptations to prolonged opioid exposure [59, 70]. According to this idea the relative inability of morphine to recruit receptor-trafficking processes means that morphine-activated $\mu$-opioid receptors continue to signal on the cell surface and thus activate adaptive processes. The main problem with this idea is that it assumes that $\mu$-opioid receptors which recycle during continuous exposure to agonists, such as methadone or enkephalin, are somehow unable to activate adaptive processes despite a continuous signal being provided by newly reinserted $\mu$-opioid receptors. There is no evidence for a different kind of signaling from uninternalized, morphine-activated $\mu$-opioid receptors and recycled agonist-activated receptors, although there is indirect evidence to suggest that these receptors may not be operationally identical [45]. Evidence for a differential induction of adaptations in HEK293 cells after chronic treatment with internalizing and non-internalizing agonists is conflicting, with some studies finding a greater superactivation of adenylyl cyclase with morphine $[59,70]$, and others reporting greater superactivation with DAMGO [69]. The theory as originally proposed also assumes that morphine does not inducesignificant receptor desensitization or internalization in neurons, assumptions which recent evidence suggests are unwarranted $[65,66,71]$. Some of the key observations of this theory have not been confirmed by other investigators $[69,72,73]$.

The second hypothesis linking $\mu$-opioid receptor trafficking to tolerance suggests that profound tolerance to morphine occurs because unrecycled receptors remain uncoupled, while receptors activated by other agonists recycle and can thus maintain signaling [36, 40, 67, 69]. This theory has been recently extended to include the notion that the continued signaling produced by recycled receptors recruits cellular adaptations more efficiently than signaling from uninternalized, desensitized receptors. This idea also means that receptor tolerance and cellular adaptations may be separable; i.e. morphine may produce tolerance without much adaptation while a drug, such as fentanyl or methadone, would produce less loss of receptor function but more adaptive changes [69]. This theory seems to be at odds with available evidence indicating that $\mu$-opioid receptor tolerance measured at the cellular level in morphine-treated animals is modest [74-77], while neuronal adaptations in the same animals are profound $[1,3,6,78]$. However, only changes associated with chronic morphine treatment have been assessed at the cellular level, and it remains to be established whether these differ quantitatively or qualitatively from those produced by agonists such as methadone or fentanyl.

Both hypotheses have some experimental support from in vitro experiments with heterologously expressed $\mu$-receptors, but they have never been directly tested on neurons. Further, neither hypothesis has really been tested beyond about $24 \mathrm{~h}$ in vitro, far shorter than in vivo opioid exposures that produce profound tolerance and adaptations. In the remainder of this review we will consider the evidence for changes in opioid receptor signaling and regulation during chronic agonist treatment, and whether these can be related to changes in opioid receptor phosphorylation.

\section{How Does Signaling Change in Chronically Agonist-Treated Animals?}

In studies that have examined $\mu$-opioid receptor responses in isolation from the adaptations produced by chronic morphine treatment, $\mu$-opioid receptor signaling is only modestly reduced. Cellular responses of neurons to efficacious agonist are usually barely altered, while responses to partial agonists such as morphine are more strongly affected, but substantial signaling capacity still remains [1, 3, 74-77]. Some studies of $\mu$-opioid receptor activation of $\mathrm{G}$ proteins in chronically morphine-treated animals have shown substantial attenuation of signaling [55], but most have reported modest decreases or little change [79-81]. There are few studies of opioid receptor signaling following chronic treatment of animals with agonists other than morphine, but intrathecal treatment with DAMGO, endomorphin-1 and endomorphin-2 all reduced $\mu$-receptor activation of $G$ proteins in the mouse spinal cord [82].

Studies in cell lines $[83,84]$ and mice $[45,85]$ have demonstrated an apparent increase in constitutive $\mu$-opioid receptor activity following treatment with morphine or other $\mu$-opioid receptor agonists. This increase in agonist-independent activity is inferred by an increase in the amount that inverse agonists inhibit basal receptor signaling. It has been suggested, but never proven, that the increases in constitutive activity are mediated by $\mu$-opioid receptor phosphorylation [45]. There is some evidence that constitutively active $\mu$-opioid receptors may preferentially signal to a different subset of $G$ proteins than 
agonist-activated receptors [83], but no evidence that they recruit different adaptations to continuously agonist-occupied receptors. Perhaps the most intriguing aspect of constitutively active receptors is the very slow time course with which the activity reverses in vivo, which will have the effect of prolonging $\mu$-opioid receptor signaling after agonists have left the tissue [85]. Constitutive $\mu$-opioid receptor activity was not detected at the level of $I_{\mathrm{Ca}}$ inhibition in locus ceruleus (LC) neurons from chronically morphine-treated rats [75] or PAG neurons from chronically morphine-treated mice [77], and the cellular consequences of signaling by constitutively active $\mu$-opioid receptors remain unknown.

\section{$\mu$-Opioid Receptor Phosphorylation in Chronically}

Agonist-Treated Animals

$\mu$-Opioid receptors continue to incorporate ${ }^{32} \mathrm{P}$ in thalamic slices from morphine-tolerant rats, and significant further phosphorylation is stimulated by exposure to DAMGO [31]. Both the basal ${ }^{32} \mathrm{P}$ incorporation and DAMGO-stimulated phosphorylation are increased in morphine-treated compared with controls. Despite the continued agonist-stimulated receptor phosphorylation, DAMGO inhibition of adenylyl cyclase activity in the same tissue was completely abolished [31], indicating that the receptors were functionally uncoupled, although it was not established if this was due to changes at the level of the $\mu$-opioid receptor or its effectors.

\section{$\mu$-Opioid Receptor Desensitization Changes in \\ Chronically Agonist-Treated Animals}

Acute desensitization of $\mu$-opioid receptor signaling is altered in chronically morphine-treated animals $[71,76]$. In LC neurons, a 10-min application of a high concentration of met-enkephalin (ME) results in a similar decline in the response in cells from vehicle or morphine-treated rats. When the ME challenge is shortened to $2 \mathrm{~min}$, there is still a profound inhibition of the subsequent response to an $\mathrm{EC}_{50}$ concentration of the peptide, which normally recovers completely within $20-25 \mathrm{~min}$. In morphinetreated rats, however, the initial reduction in the LC response to the $\mathrm{EC}_{50}$ concentration of $\mathrm{ME}$ is significantly greater and the recovery of this response is significantly reduced at $25 \mathrm{~min}$. Similar observations were made for morphine and morphine-6-glucuronide [71, 76].

\section{$\mu$-Opioid Receptor-Trafficking Changes in}

Chronically Agonist-Treated Animals

$\mu$-Opioid receptor trafficking in chronically morphinetreated animals has only been directly examined in one study [86], although a relative increase in intracellular versus plasma membrane $\mu$-opioid receptor immunoreactivity was found in brainstem neurons from morphinetreated rats [87]. In the study where trafficking was examined there was a significant reduction in DAMGO-mediated anti-nociception in the treated animals but no change in the amount of $\mu$-opioid receptor internalization in response to DAMGO [86]. There was also no difference in the basal amount of intracellular $\mu$-opioid receptor immunoreactivity, despite the continued presence of morphine in the rats. These data suggest that $\mu$-opioid receptors are still trafficked in response to an agonist even though they are presumably less effectively coupled to intracellular effectors. The results also show that chronic morphine has not induced receptor modifications that render receptors resistant to trafficking machinery. It will be fascinating to find out whether the protein kinases involved in facilitating $\mu$-receptor internalization in chronically morphine-treated animals are the same as those involved in naïve animals, particularly in light of the recent suggestion that GRK2 is only involved in the first but not subsequent rounds of $\mu$-opioid receptor trafficking in HEK293 cells [43].

The desensitization and recovery of $\mu$-opioid receptor responses in LC neurons has been attributed to receptor uncoupling followed by internalization and recycling [71, 88], although it has not yet been possible to directly visualize these processes in LC neurons. Monensin, which interferes with receptor recycling to the plasma membrane, increases the steady-state desensitization produced by ME in LC neurons and inhibits $\mu$-opioid receptor recovery from desensitization, implying that relatively rapid receptor trafficking mediates a component of acute $\mu$ opioid receptor desensitization. Monensin still potentiates the initial ME desensitization and further slows the already compromised recovery from desensitization in morphine-treated rats, providing further evidence that receptor-trafficking processes persist in morphine-treated animals [71].

The evidence that reversal of acute $\mu$-opioid receptor desensitization is compromised in LC neurons from morphine-treated rats indicates that there may be an alteration in some aspect of the receptor-trafficking pathway. Changes in the expression of a number of proteins putatively involved in $\mu$-opioid receptor trafficking have been reported in chronically $\mu$-opioid agonist-treated animals, although these changes can be agonist-dependent and are not always observed with morphine treatment $[7,89,90]$. It is not known whether these changes occur in $\mu$-opioid receptor-expressing neurons or others cells that are parts 
of neuronal circuits affected by adaptations to chronic $\mu$ opioid receptor agonist treatment. Importantly, because crucial trafficking proteins are utilized by many GPCRs, changes in GRK, dynamin or arrestin levels are likely to affect the regulation of multiple neurotransmitter receptors in opioid-sensitive neuronal circuits. Such changes in the regulation of other GPCRs may be an adaptation to chronic opioid treatment, although there is no direct evidence for this.

\section{Responses to Chronic Morphine Treatment of Animals Lacking Proteins Involved in $\mu$-Opioid Receptor Trafficking}

GRK3 knockout mice displayed similar anti-nociceptive responses to fentanyl and morphine as wild-type littermates, but tolerance to prolonged treatment with fentanyl (but not morphine) was attenuated [50]. The signs of naloxone precipitated withdrawal from chronic fentanyl treatment were similar in GRK3 null and wild-type mice, implying that adaptations to chronic fentanyl treatment persisted in these animals [48].

Arrestin 3 deletion mice are more sensitive to the acute anti-nociceptive and hypothermic effects of morphine and display elevated baseline nociceptive sensitivity in some tests $[54,56]$. Arrestin 3 knockout animals develop no tolerance to the anti-nociceptive effects of morphine in some behavioral tests while in others the development of tolerance is significantly delayed [54, 56]. However, like the GRK 3 knockout mice animals, the arrestin 3 null animals display similar signs of naloxone-precipitated withdrawal to chronically treated wildtype mice [55]. The ubiquitous upregulation of adenylyl cyclase activity produced by chronic morphine treatment is also similar in striatal membranes from each genotype of mouse [55]. The anti-nociceptive tolerance to morphine in wild-type mice was accompanied by a complete loss of DAMGO-stimulated G-protein activation in the brain, while there was only a small loss of activity in arrestin 3 knockout animals, indicating that arrestin 3 deletion prevented uncoupling of $\mu$-opioid receptors [55]. The complete uncoupling of the $\mu$-opioid receptor is difficult to reconcile with the persistence of morphine-induced analgesia in the tolerant animals and is in contrast to previous studies that used much higher doses of morphine in chronic treatment paradigms [1, $71,74-77,80,81]$. The apparent complete loss of $\mu$-opioid receptor activity in wild-type mice also begs the question of how receptors which no longer signal to $G$ proteins promote adaptations in adenylyl cyclase as efficiently as those in the arrestin 3 knockouts, where recep- tor signaling is enhanced compared to normal, even after chronic agonist treatment.

Studies to date in GRK3 or arrestin 3 knockout mice have not provided a clear test of the hypothesis that $\mu$ opioid receptor phosphorylation and/or trafficking is involved in adaptations to chronic opioid treatment. Most importantly, neither $\mu$-opioid receptor phosphorylation nor trafficking have been directly examined in these animals. These experiments are difficult, but the next most useful experiments, those examining functional responses of single $\mu$-opioid-sensitive neurons, have also not been reported. While it is tempting to speculate that the changes in opioid analgesic tolerance in GRK3 and arrestin 3 knockout animals result from changes in $\mu$-opioid receptor function, GRK3 and arrestin 3 likely regulate dozens of other GPCRs involved in regulating the activity of opioid-sensitive circuits in mice. Further, the emerging role of arrestins as active transducers of receptor signaling [91] raise the possibilities that the changes observed in both arrestin 3 and GRK3 animals result from altered consequences of $\mu$-receptor activation rather than changes in $\mu$-receptor regulation.

\section{Other Possible Roles of $\mu$-Receptor Phosphorylation and Trafficking in Chronically Opioid-Treated Animals}

In contrast to animals treated with morphine, where changes in $\mu$-receptor amounts are generally modest [9294], chronic treatment of mice with high-efficacy/high-affinity opioid agonists, such as etorphine or sufentanil, results in a reliable downregulation of $\mu$-opioid receptors [94-96]. Presumably this loss of receptor protein occurs after removal of the receptor from the cell surface by arrestin-dependent trafficking. It is possible that receptor protein is lost through repeated rounds of trafficking in the continued presence of agonist, each round of internalization/recycling resulting in the loss of a small portion of the internalized receptors. In HEK293 cells about 20\% of $\mu$-opioid receptors are degraded in lysosomes during each round of trafficking [68], although whether this is the case in neurons in not known. How (or whether) $\mu$ opioid receptors are tagged for degradation rather than recycling is not known, but it is conceivable that agonistdependent phosphorylation events may signal this - either a greater overall receptor phosphorylation in response to a high-efficacy agonist or phosphorylation of distinct residues to those phosphorylated in response to morphine binding to the receptor [28]. 


\section{Conclusion}

Continued opioid receptor signaling provides the engine for neuronal adaptations that are largely responsible for the whole animal phenomena of tolerance and dependence. Most evidence suggests that alterations in receptor signaling per se are limited in chronically agonist-treated animals, with limited evidence for alterations in the complement of $\mathrm{G}$ proteins activated by opioid receptors, or an increase in any non-G protein-mediated signaling. Acute opioid receptor phosphorylation is correlated with a reduction in receptor-signaling capacity, but there is no evidence that basal or agonist-induced $\mu$-opioid receptor phosphorylation changes in chronically treated animals in vivo. $\mu$-Opioid receptor-trafficking processes persist in chronically agonist-treated animals, and there are no good reasons to believe that receptor trafficking does anything other than resensitize or downregulate receptors in a manner similar to what has been observed in vitro. Thus, to the extent that receptor phosphorylation and trafficking maintain signaling through the $\mu$-opioid receptor, these two events are crucial in facilitating the adaptations to chronic opioid treatment. What remains to be established in vivo is just how important receptor traf- ficking is to maintaining receptor signaling in response to chronic treatment with pharmacologically relevant doses of drug. Despite the apparent failure of morphine to produce as much $\mu$-opioid receptor phosphorylation or trafficking as some other agonists, it remains to be established that the neuronal adaptations produced by morphine are any different to those produced by other analgesic opioids such as methadone or fentanyl. Nevertheless, despite the identification of many adaptations to chronic opioid agonist treatment, the molecular mechanisms underlying even the most basic of these - the upregulation of neuronal adenylyl cyclase activity - remain to be definitively established. Until more is known about how animals adapt to chronic opioid treatment, the possibility that agonist-specific phosphorylation or receptor trafficking can contribute to the induction or maintenance of different adaptations remains open.

\section{Acknowledgments}

Supported by NH\&MRC of Australia Project Grant 302002 to M.C., and National Institute on Drug Abuse DA12926-01 to M.J.C. We thank Vu Dang for his helpful discussions.

\section{References}

1 Hack SP, Vaughan CW, Christie MJ: Modulation of GABA release during morphine withdrawal in midbrain neurons in vitro. Neuropharmacology 2003;45:575-584.

2 Ossipov MH, Lai J, King T, Vanderah TW, Malan Jr TP, Hruby VJ, Porecca F: Antinociceptive and nociceptive actions of opioids. J Neurobiol 2004;61:126-148.

-3 Bagley EE, Gerke MB, Vaughan CW, Hack SP, Christie MJ: GABA transporter currents activated by protein kinase A excite midbrain neurons during opioid withdrawal. Neuron 2005; 45:433-445.

4 Bie B, Pan ZZ: Increased glutamate synaptic transmission in the nucleus raphe magnus neurons from morphine-tolerant rats. Mol Pain 2005;1:7. doi:10.1 186/1744-8069-1-7.

-5 Saal D, Dong Y, Bonci A, Malenka RC: Drugs of abuse and stress trigger a common synaptic adaptation in dopamine neurons. Neuron 2003;37:577-582

-6 Williams JT, Christie MJ, Manzoni O: Cellular and synaptic adaptations mediating opioid dependence. Physiol Rev 2001;81:299-343.

7 Bailey CP, Connor M: Opioids: cellular mechanisms of tolerance and physical dependence. Curr Opin Pharmacol 2005;5:60-68.

8 Liu-Chen L-Y: Agonist-induced regulation and trafficking of $\kappa$ opioid receptors. Life Sci 2004; 75:511-536
9 Varga EV, Navratilova E, Stropova D, Jambrosic J, Roeske WR, Yamamura HI: Agonistspecific regulation of the $\delta$-opioid receptor. Life Sci 2004;76:599-612.

10 Gintzler AR, Chakrabarti S: Chronic morphine-induced plasticity among signalling molecules. Novartis Found Symp 2004;261: 167-176.

11 Connor M, Christie MJ: Opioid receptor signalling mechanisms. Clin Exp Pharmacol Physiol 1999;26:493-499.

12 Maudsley S, Martin B, Luttrell LM: The origins of diversity and specificity in $G$ proteincoupled receptor signaling. J Pharmacol Exp Ther 2005;314:485-494.

13 Segredo V, Burford NT, Lameh J, Sadee W: A constitutively internalizing and recycling mutant of the $\mu$-opioid receptor. J Neurochem 1997; 68:2395-2404.

14 Burford NT, Wang D, Sadee W: G-protein coupling of $\mu$-opioid receptors $\left(\mathrm{OP}_{3}\right)$ : elevated basal signalling activity. Biochem J 2000;348: 531-537.

15 Ingram S, Wilding TJ, McCleskey EW, Williams JT: Efficacy and kinetics of opioid action on acutely dissociated neurons. Mol Pharmacol 1997;52:136-143
16 Connor M, Osborne P, Christie MJ: $\mu$-Opioid receptor desensitization: is morphine different? Br J Pharmacol 2004; 143:685-696.

17 Kobrinsky E, Mirshahi T, Zhang H, Jin T, Logothetis DE: Receptor-mediated hydrolysis of plasma membrane messenger $\mathrm{PIP}_{2}$ leads to $\mathrm{K}+$-current desensitization. Nat Cell Biol 2000;2:507-514

18 Nomura K, Reuveny E, Narahashi T: Opioid inhibition and desensitization of calcium channel currents in rat dorsal root ganglion neurons. J Pharmacol Exp Ther 1994;270: 466-474

19 Von Zastrow M, Svingos A, Haberstock-Debic Evans C: Regulated endocytosis of opioid receptors: cellular mechanisms and proposed roles in physiological adaptation to opioid drugs. Curr Opin Neurobiol 2003;13:348353.

20 Garzon J, Rodriguez-Munoz M, de la TorreMadrid E, Sanchez-Blazquez P: Effector antagonism by the regulators of $\mathrm{G}$ protein signalling (RGS) proteins causes desensitization of mu-opioid receptors in the CNS. Psychopharmacology 2005;180:1-11.

21 Xie G-X, Palmer PP: RGS proteins: new players in the filed of opioid signaling and tolerance mechanisms. Anesth Analg 2005;100:10341042 . 
-22 Garzon J, Rodriguez-Munoz M, Lopez-Fernando A, Sanchez-Blazquez P: Activation of $\mu$-opioid receptors transfers control of $\mathrm{G} \alpha$ subunits to regulator of G-protein signalling RGS9-2. J Biol Chem 2005;280:8951-8960.

-23 Zachariou V, Georgescu D, Sanchez N, Rahman Z, DiLeone R, Berton O, Neve RL, SimSelley LJ, Selley DE, Gold SJ, Nestler EJ: Essential role for RGS9 in opiate action. Proc Natl Acad Sci USA 2003;100:13656-13661.

24 Ferguson SSG: Evolving concepts in G protein-coupled receptor endocytosis: the role in receptor desensitisation and signaling. Pharmacol Rev 2001;53:1-24.

25 Daaka Y, Luttrell LM, Lefkowitz RJ: Switching of the coupling of the $\beta 2$-adrenergic receptor to different $\mathrm{G}$ proteins by protein kinase $\mathrm{A}$. Nature 1997;390:88-91.

-26 Chavkin C, McLaughlin JP, Celver JP: Regulation of opioid receptor function by chronic agonist exposure: constitutive activity and desensitization. Mol Pharmacol 2001;60:20-25.

-27 El Kouhen R, Burd AL, Erickson-Herbrandson LJ, Chang C-Y, Law P-Y, Loh HH: Phosphorylation of $\mathrm{Ser}^{363}, \mathrm{Thr}^{370}$ and $\mathrm{Ser}^{375}$ residues within the carboxyl tail differentially regulates $\mu$-opioid receptor internalization. $\mathbf{J}$ Biol Chem 2001;276:12744-12780.

$\checkmark 28$ Schulz S, Mayer D, Pfeiffer M, Stumm R, Koch T, Hollt V: Morphine induces terminal $\mu$-opioid receptor desensitization by sustained phosphorylation of serine-375. EMBO J 2004; 23:3282-3289.

-29 Seibold A, Williams B, Huang Z-F, Friedman J, Moore RH, Knoll BJ, Clark RB: Localization of the sites mediating desensitization of the $\beta 2$ adrenergic receptor by the GRK pathway. Mol Pharmacol 2000;58:1162-1173.

- 30 Trester-Zedlitz M, Burlingame A, Kobilka B, von Zastrow M: Mass spectrophotometric analysis of agonist effects on posttranslational modifications of the beta-2 adrenoceptor in mammalian cells. Biochemistry 2005; 44: 6133-6143.

-31 Deng HB, Yu Y, Wang H, Guang W, Wang JB: Agonist-induced $\mu$ opioid receptor phosphorylation and functional desensitization in rat thalamus. Brain Res 2001;898:204-214.

- 32 Arden JR, Segredo V, Wang Z, Lameh J, Sadee W: Phosphorylation and agonist-specific intracellular trafficking of an epitope-tagged $\mu$-opioid receptor expressed in HEK 293 cells. J Neurochem 1995;65:1636-1645.

-33 Zhang L, Yu Y, Mackin S, Weight FF, Uhl GR, Wang JB: Differential $\mu$ opiate receptor phosphorylation and desensitization induced by agonists and phorbol esters. J Biol Chem 1996; 271:11449-11454.

34 Wang Z, Arden J, Sadee W: Basal phosphorylation of $\mu$ opioid receptor is agonist modulated and $\mathrm{Ca}^{2+}$-dependent. FEBS Lett 1996;386:5357.

35 Yu Y, Zhang L, Yin X, Sun H, Uhl GR, Wang JB: $\mu$-Opioid receptor phosphorylation, desensitization and ligand efficacy. $\mathrm{J}$ Biol Chem 1997;272:28869-28874.
Zhang J, Ferguson SSG, Barak LS, Bodduluri SR, Laporte SA, Law P-Y, Caron MG: Role for $\mathrm{G}$ protein-couple receptor kinase in agonistspecific regulation of $\mu$-opioid receptor responsiveness. Proc Natl Acad Sci USA 1998;95: 7157-7162.

37 Whistler JL, Chuang HH, Chu P, Jan LY, von Zastrow M: Functional dissociation of $\mu$-opioid receptor signaling and endocytosis: implications for the biology of opiate tolerance and addiction. Neuron 1999;23:737-746.

-38 El Kouhen R, Maestri-El Kouhen O, Law P-Y, Low HH: The absence of a direct correlation between the loss of $\left[\mathrm{D}-\mathrm{Ala}^{2}, \mathrm{~N}-\mathrm{MePhe}{ }^{4} \mathrm{Gly}^{5}\right.$ ol] enkephalin inhibition of adenylyl cyclase activity and agonist-induced $\mu$-opioid receptor phosphorylation. J Biol Chem 1999;274:92079215.

39 Deng HB, Yu Y, Pak Y, O’Dowd BF, George SR, Surratt CK, Uhl GR, Wang JB: Role for the C-terminus in agonist-induced $\mu$-opioid receptor phosphorylation and desensitization. Biochemistry 2000;39:5492-5499.

40 Koch T, Schulz S, Pfeiffer M, Klutzny M, Schroder $\mathrm{H}$, Kahl E, Hollt V: C-terminal splice variants of the mouse $\mu$-opioid receptor differ in morphine-induced internalization and receptor resensitization. J Biol Chem 2001;276: 31408-31414.

41 Chakrabarti S, Law P-Y, Low HH: Distinct differences between morphine and $\left[\mathrm{D}-\mathrm{Ala}^{2}, \mathrm{~N}\right.$ $\mathrm{MePhe}^{4} \mathrm{Gly}^{5}$-ol]enkephalin- $\mu$-opioid receptor complexes demonstrated by cyclic AMP-dependent protein kinase phosphorylation. J Neurochem 1998;71:231-239.

42 McLaughlin JP, Chavkin C: Tyrosine phosphorylation of the $\mu$-opioid receptor regulates intrinsic agonist efficacy. Mol Pharmacol 2001; 59:1360-1368.

43 Kenski DM, Zhang C, von Zastrow M, Shokat $\mathrm{KM}$ : Chemical genetic engineering of $\mathrm{G}$ protein-coupled receptor kinase 2. J Biol Chem 2005;280:35051-35061.

-44 Schulz R, Wehmeyer A, Schulz K: Opioid receptor types selectively cointernalize with $\mathrm{G}$ protein-coupled receptor kinases 2 and 3. J Pharmacol Exp Ther 2002;300:376-384.

45 Sadee W, Wang D, Bilsky EJ: Basal opioid receptor activity, neutral antagonists, and therapeutic opportunities. Life Sci 2005;76:14271437.

-46 Strulovici B, Cerione R, Kilpatrick BF, Caron MG, Lefkowitz RJ: Direct demonstration of impaired functionality of a purified desensitized $\beta$-adrenergic receptor in an reconstituted system. Science 1984; 225: 837-840.

47 Gurevich VV, Dion SB, Onorato JJ, Ptasienski J, Kim CM, Sterne-Marr R, Hosey MM, Benovic JL: Arrestin interactions with G proteincoupled receptors. J Biol Chem 1995;270:720731.

48 Gurevich VV, Gurevich EV: The molecular acrobatics of arrestin activation. Trends Pharmacol Sci 2004;25:105-111.
49 Bailey CP, Kelley EP, Henderson G: Protein kinase $\mathrm{C}$ activation enhances morphine-induced rapid desensitization of $\mu$-opioid receptors in mature rat locus ceruleus neurons. Mol Pharmacol 2004;66:1592-1598.

-50 Terman GW, Jin W, Cheong Y-P, Lowe J, Caron MG, Lefkowitz RJ, Chavkin C: G-protein receptor kinase 3 (GRK3) influences opioid analgesic tolerance but not opioid withdrawal. Br J Pharmacol 2004;141:55-64.

- 51 Oakley RH, Laporte SA, Holt JA, Caron MG, Barak LS: Differential affinities of visual arrestin, ßarrestin 1 and ßarrestin2 for G proteincoupled receptors delineate two major classes of receptors. J Biol Chem 2000;275:1720117210.

-52 Bushell T, Endoh T, Simen AA, Ren D, Bindokas VP, Miller RJ: Molecular components of tolerance to opiates in single hippocampal neurons. Mol Pharmacol 2002;61:55-64.

53 Bohn LM, Dykstra LA, Lefkowitz RJ Caron MG, Barak LS: Relative opioid efficacy is determined by the complements of the $\mathrm{G}$ proteincoupled receptor desensitization machinery. Mol Pharmacol 2004;66:106-112.

-54 Bohn LM, Lefkowitz RJ, Gainetdinov RR, Peppel K, Caron MG, Lin, FT: Enhanced morphine analgesia in mice lacking $\beta$-arrestin 2 . Science 1999;286:2495-2498.

-55 Bohn LM, Gainetdinov RR, Lin F, Lefkowitz RJ, Caron, MG: $\mu$-Opioid receptor desensitization by $\beta$-arrestin- 2 determines morphine tolerance but not dependence. Nature 2000; 408:720-723.

56 Bohn LM, Lefkowitz RJ, Caron MG: Differential mechanisms of morphine antinociceptive tolerance revealed in ßarrestin-2 knockout mice. J Neurosci 2002;22:10494-10500.

57 Sternini C, Spann M, Anton B, Keith Jr DE, Bunnet NW, von Zastrow M, Evans C, Brecha $\mathrm{NC}$ : Agonist selective endocytosis of $\mu$-opioid receptor by neurons in vivo. Proc Natl Acad Sci USA 1996;93:9421-9426.

58 Trafton JA, Abbadie C, Marek K, Basbaum AI: Postsynaptic signaling via the $\mu$-opioid receptor: responses of dorsal horn neurons to exogenous opioids and noxious stimulation. J Neurosci 2000;20:8578-8584.

$59 \mathrm{He}$ L, Fong J, von Zastrow M, Whistler JL: Regulation of opioid receptor trafficking and morphine tolerance by receptor oligomerization. Cell 2002;108:271-282.

60 Lee M-C, Cahill CM, Vincent J-P, Beaudet A: Internalization and trafficking of opioid receptor ligands in rat cortical neurons. Synapse 2002;43:102-111.

61 Keith DE, Murray SR, Zaki PA, Chu PC, Lissin DV, Kang L, Evans CJ, von Zastrow M: Morphine activates opioid receptors without causing their rapid internalization. $\mathrm{J}$ Biol Chem 1996;271:19021-19024.

62 Keith DE, Anton B, Murray SR, Zaki PA, Chu PC, Lissin DV, Monteillet-Agius G, Stewart PL, Evans CJ, von Zastrow M: $\mu$-Opioid receptor internalization: opiate drugs have differential effects on a conserved endocytic mechanism in vitro and the mammalian brain. $\mathrm{Mol}$ Pharmacol 1998;53:377-384. 
63 Borgland SL, Connor M, Osborne PB, Furness JB, Christie MJ: Opioid agonists have different efficacy profiles for $\mathrm{G}$ protein activation, rapid desensitization and endocytosis of mu-opioid receptors. J Biol Chem 2003;278:1877618784.

- 64 Celver J, Xu M, Jin W, Lowe J, Chavkin C: Distinct domains of the $\mu$-opioid receptor control uncoupling and internalization. Mol Pharmacol 2004;65:528-537.

65 Haberstock-Debic H, Kim K-A, Yu YJ, von Zastrow M: Morphine promotes rapid, arrestin-dependent endocytosis of $\mu$-opioid receptors in striatal neurons. J Neurosci 2005;25: 7847-7857.

66 Haberstock-Debic H, Wein M, Barrot M, Colago EEO, Rahman Z, Neve RL, Pickel VM, Nestler EJ, von Zastrow M, Svingos AL: Morphine acutely regulates opioid receptor trafficking selectively in dendrites of nucleus accumbens neurons. J Neurosci 2003;23: 4324-4332.

- 67 Koch T, Schulz S, Schroder H, Wolf R, Raulf E, Hollt V: Carboxyl-terminal splicing of the rat $\mu$-opioid receptor modulates agonist-mediated internalization and receptor resensitization. J Biol Chem 1998;273:13652-13667.

68 Tanowitz M, von Zastrow M: A novel endocytic recycling signal that distinguishes the membrane trafficking of naturally occurring opioid receptors. J Biol Chem 2003;278: 45978-45986.

-69 Koch T, Widera A, Bartzsch K, Schulz S, Brandenburg L-O, Wundrack N, Beyer A, Grecksch G, Hollt V: Receptor endocytosis counteracts the development of tolerance. Mol Pharmacol 2005;67:280-287.

70 Finn AK, Whistler JL: Endocytosis of the mu opioid receptor reduces tolerance and a cellular hallmark of withdrawal. Neuron 2001;32:829_ 839.

-71 Dang V, Williams JT: Morphine-induced $\mu$ opioid receptor desensitization. Mol Pharmacol 2005;68:1127-1132.

-72 Bailey CP, Couch D, Johnson E, Griffiths K, Kelly E, Henderson G: $\mu$-Opioid receptor desensitization in mature rat neurons: lack of interaction between DAMGO and morphine. J Neurosci 2003;23:10515-10520.

-73 Blanchet C, Sollini M, Luscher C: Two distinct forms of desensitization of G-protein coupled inwardly rectifying potassium currents evoked by alkaloid and peptide $\mu$-opioid receptor agonists. Mol Cell Neurosci 2003;24:517-523.
74 Christie MJ, Williams JT, North RA: Cellular mechanisms of opioid tolerance: studies in single brain neurons. Mol Pharmacol 1987;32: 633-638.

75 Connor M, Borgland SL, Christie MJ: Continued morphine modulation of calcium channel currents in acutely isolated locus coeruleus neurons from morphine-dependent rats. $\mathrm{Br} \mathrm{J}$ Pharmacol 1999; 128:1561-1569.

76 Dang V, Williams JT: Chronic morphine treatment reduces recovery from desensitization. $\mathrm{J}$ Neurosci 2004;24:7699-7706.

77 Bagley EE, Chieng BCH, Christie MJ, Connor $\mathrm{M}$ : Opioid tolerance in periaqueductal gray mouse neurons isolated from mice chronically treated with morphine. Br J Pharmacol 2005; 146:68-76.

78 Dumont E, Williams JT: Noradrenaline triggers $\mathrm{GABA}_{\mathrm{A}}$ inhibition of bed nucleus of the stria terminalis neurons projecting to the ventral tegmental area. J Neurosci 2004;81988204.

79 Sim LJ, Selley DE, Dworkin SI, Childers SR: Effects of chronic morphine administration on $\mu$-opioid receptor-stimulated $\left[{ }^{35} \mathrm{~S}\right]-\mathrm{GTP} \gamma \mathrm{S}$ autoradiography in rat brain. J Neurosci 1996; 16 : 2684-2692.

80 Sim-Selley LJ, Selley DE, Vogt LJ, Childers SR, Martin TJ: Chronic heroin self-administration desensitizes $\mu$ opioid receptor-activated G-proteins in specific regions of rat brain. J Neurosci 2000;20:4555-4562.

81 Kirschke C, Schadrack J, Zieglgansberger W, Spangler R: Effects of morphine withdrawal on $\mu$-opioid receptor-stimulated guanylyl $55^{\prime}-[\gamma$ $\left[{ }^{35}\right.$ S]thio]-triphosphate autoradiography in rat brain. Eur J Pharmacol 2002;446:43-51. 82 Narita M, Mizoguchi H, Narita M, Nagase H,
Suzuki T, Tseng LF: Involvement of spinal protein kinase $\mathrm{C} \gamma$ in the attenuation of opioid $\mu$-receptor-mediated G-protein activation after chronic intrathecal administration of [D$\left.\mathrm{Ala}^{2}, N-\mathrm{MePhe}^{4}, \mathrm{Gly}-\mathrm{ol}^{5}\right]$ enkephalin. J Neurosci $2001 ; 21: 3715-3720$.

83 Liu JG, Ruckle MB, Prather PL: Constitutively active $\mu$-opioid receptors inhibit adenylyl cyclase activity in intact cells and activate Gproteins differently than the agonist $\left[\mathrm{D}-\mathrm{Ala}^{2}, \mathrm{~N}\right.$ $\mathrm{MePhe}^{4}, \mathrm{Gly}_{\mathrm{ol}}{ }^{5}$ ]enkephalin. J Biol Chem 2001;276:37779-37786.

-84 Liu JG, Prather PL: Chronic exposure $\mu$-opioid agonists produces constitutive activation of $\mu$-opioid receptors in direct proportion to the efficacy of the agonist used for pretreatment. Mol Pharmacol 2001;60:53-62.
85 Wang D, Raehal KM, Lin ET, Lowery JJ, Kieffer BL, Bilsky EJ, Sadee W: Basal signaling activity of $\mu$-opioid receptor in mouse brain: role in narcotic dependence. J Pharmacol Exp Ther 2004;308:612-620.

86 Trafton JA, Basbaum AI: $\left[\mathrm{D}-\mathrm{Ala}^{2}, N\right.$ $\mathrm{MePhe}^{4}, \mathrm{Glyol}^{5}$ ]enkephalin-induced internalization of the $\mu$-opioid receptor in the spinal cord of morphine tolerant rats. Neuroscience 2004; 125:541-543.

-87 Drake CT, Aicher SA, Montalmant FL, Milner TA: Redistribution of mu-opioid receptors in $\mathrm{C} 1$ adrenergic neurons following chronic administration of morphine. Exp Neurol 2005; 196:365-372.

88 Alvarez VA, Arttamangkul S, Dang V, Salem A, Whistler JL, von Zastrow M, Grandy DK, Williams JT: $\mu$-Opioid receptors: ligand-dependent activation of potassium conductance, desensitization, and internalization. J Neurosci 2002;22:5769-5776.

89 Terwilliger RZ, Ortiz J, Guitart X, Nestler EJ: Chronic morphine administration increases $\beta$ adrenergic receptor kinase ( $\beta$ ARK) levels in the rat locus coeruleus. J Neurochem 1994;63: 1983-1986.

90 Patel MB, Patel CN, Rajashekara V, Yoburn BC: Opioid agonists differentially regulate $\mu$ opioid receptor trafficking proteins in vivo. Mol Pharmacol 2002;62:1464-1470.

91 Lefkowitz RJ, Shenoy SK: Transduction of receptor signals by $\beta$-arrestins. Science 2005; 308:512-517.

92 Werling LL, McMahon PN, Cox BM: Selective changes in $\mu$ opioid receptor properties induced by chronic morphine exposure. Proc Natl Acad Sci USA 1989;86:6393-6397.

93 Bhargava HN, Gulati A: Down-regulation of brain and spinal cord $\mu$-opiate receptors in morphine tolerant-dependent rats. Eur J Pharmacol 1990; 190:305-311.

94 Yoburn BC, Purohit V, Patel K, Zhang Q: Opioid agonist and antagonist treatment differentially regulates immunoreactive $\mu$-opioid receptors and dynamin-2 in vivo. Eur J Pharmacol 2004;498:87-96.

95 Tao PL, Law PY, Loh HH: Decrease in delta and mu opioid receptor binding capacity in rat brain after chronic etorphine treatment. J Pharmacol Exp Ther 1987;240:809-816.

-96 Diaz A, Ruiz F, Florez J, Hurle MA, Pazos A: $\mathrm{Mu}$-opioid receptor regulation during opioid tolerance and supersensitivity in rat central nervous system. J Pharmacol Exp Ther 1995; 274:1545-1551. 